\title{
種々のプラスチックチューブ内に点弧された 溶発アークの電界の強さと溶発ガス量
}

$\begin{array}{lllll}\text { 正員 滝 川 } 川 \text { 浩 史 } & \text { (豊橋技科大) } \\ \text { 学生員 大 } & \text { 西 } & \text { 隆 } & \text { (豊橋技科大) } \\ \text { 正 員 㭊 } & \text { 原 } & \text { 建 } & \text { 樹 } & \text { (豊橋技科大) }\end{array}$

Electric Field Strengths of the Arcs Burning through Various Plastic Tubes and their Ablation Gas Volumes

Hirofumi Takikawa, Member, Ryuji Ohnishi, Student Member, Tateki Sakakibara, Member (Toyohashi University of Technology)

Electric field strength of the arcs burning through plastic tubes (PE, PP, PMMA, POM, PA, ABS, PVC, PTFE) at atmospheric pressure are measured as a function of arc current $(2 \sim 500 \mathrm{~A})$ for various tube inner diameters $(2,4$, and $6 \mathrm{~mm} \phi)$. Tube lengths are $10 \sim 30 \mathrm{~mm}$. The result shows that, as the curent increases, the electric field strenght decreases in lower current range and increases in higher current range. In lower current range, the electric field strength depends on the material : the electric field strength of PTFE arc is the lowest, that of PVC arc is higher than that of PTFE arc and those of the other material arcs are higher than that of PVC arc. In higher current range, as the current increases, the difference becomes small.

The gas volume ablated from the tube wall by the arc is measured for various tube materials and the arc currents. The result shows that the relationship between the ablation gas volume and the electric field strength in lower current range is linear if the current is constant, whereas that in higher current range is linear regardless of the tube material or the arc current.

キーワード：プラスチックチューブ, 溶発アーク, 電界の強さ, チューブ損耗量, 溶発ガス量

\section{1.まえがき}

近年, 電力用機器の絶縁材料として, 種々のプラスチッ ク材料が用途や条件に応じて用いられてきている。そのプ ラスチック材料の内部や近傍でアークが発生すると, アー クの熱によってプラスチック材料が溶発し，アークはその 溶発ガス雾囲気中に存在することになる。このような形態 のアークは, 溶発アーク (ablation arc) と呼ばれる。こ れまで研究の対象とされたプラスチック材料は，ポリ塩 化ビニル $\left(\mathrm{PVC} ; \mathrm{C}_{2} \mathrm{H}_{3} \mathrm{Cl}\right)^{(1)}$ ，ポリアセタル (POM ; $\left.\mathrm{CH}_{2} \mathrm{O}\right)^{(2)}$, アクリル (PMMA $\left.\mathrm{C}_{5} \mathrm{H}_{8} \mathrm{O}_{2}\right)^{(3)-(5)}$, テフロン $\left(\mathrm{PTFE} ; \mathrm{C}_{2} \mathrm{~F}_{4}\right)^{(5) \sim(8)}$, ナイロン[PA; $\mathrm{NH}\left(\mathrm{CH}_{2}\right)_{x} \mathrm{NH}-$ $\left.\mathrm{CO}\left(\mathrm{CH}_{2}\right)_{y-2} \mathrm{CO}\right)^{(5)(9)}$, ポリエチレン $\left(\mathrm{PE} ; \mathrm{C}_{2} \mathrm{H}_{4}\right)^{(8)(10) \sim(12)}$ などである。しかしながら, 同一条件において, 材料の違 いによるアーク特性の変化を明らかにした報告はない。

著者らは，これまでプラスチック材料として PE を取り 上げ，PEチューブ内に点弧した低電流のアークに関し， 電界の強さ ${ }^{(10)}$, 温度分布 ${ }^{(1)}$, 流速 ${ }^{(12)}$ などを計測してき
た。本論文では，PEのほかに，PVC，PTFE，ポリプロ ピレン $\left(\mathrm{PP} ; \mathrm{C}_{3} \mathrm{H}_{6}\right), \mathrm{PMMA}$, ジュラコン (ポリアセタ ル), $\mathrm{PA}$ ，および ABS 樹脂 ( $\mathrm{ABS} ; \mathrm{C}_{9} \mathrm{H}_{12} \mathrm{~N}_{1}$ ) を対象 に，それらのチューブ内に点弧した大気圧アークプラズマ の電界の強さを，直流電源およびコンデンサ電源を用いて 計測している。更に，プラスチック材料の損耗量抢よび溶 発ガス量を計測し, 電界の強さとの関係を明らかにしてい る。

なお，本論文では，各種プラスチック材料のチューブ内 に点弧させたアークを，それぞれの材料の名前を冠し，例 えばPEアークとか PVCアークと呼ぶことにする。実験 条件は, チューブ孔径: $2,4,6 \mathrm{~mm} \phi$, チューブ長： 10〜30 mm，電流領域：2〜500 A とした。

\section{2. 低電流領域（2３0 A）における電界の強さ}

$\langle 2 \cdot 1\rangle$ 実験方法 アーク発生装置, 電源回路構成, および計測系を図 1 に示す。銅製水冷陽極と陰極との間に プラスチックチューブを軸方向に配置し(10)，チュープ両 


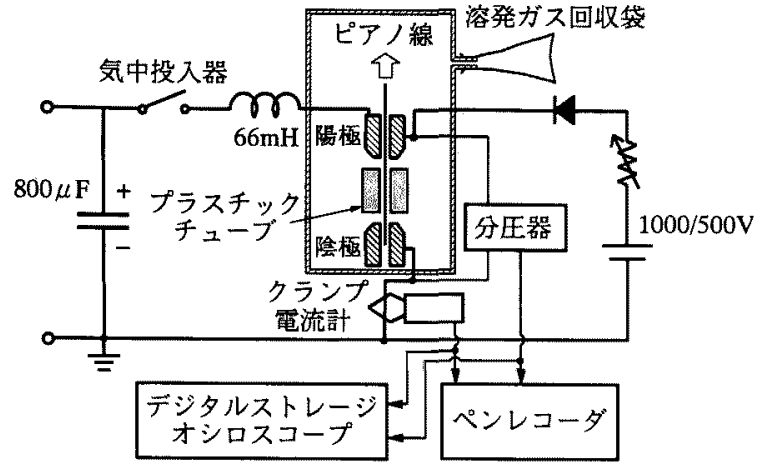

図 1 プラスチック溶発アーク発生回路と計測系 Fig. 1. Plastic ablation arc device and measurement system.

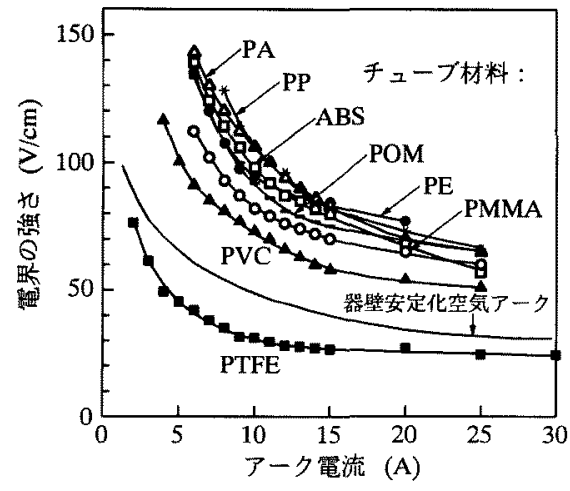

図 2 低電流領域に扔ける電界の強さ一電流特性 Fig. 2. Electric field strength-current characteristics in the range of $2 \sim 30 \mathrm{~A}$.

端と陰・陽極との距離を $5 \mathrm{~mm}$ 一定に保持した。直流電源 $(100 / 500 \mathrm{~V}, 30 \mathrm{kVA})$ と電流制限用可変抵抗とからなる 右側の回路を用いて，2〜30 A の低電流のアークを発生さ せた。ピアノ線を高速に引き抜くことによって, チューブ 内にアークを点弧させた。電極間ギャップ長の長さを 30 $\mathrm{mm}$ とした場合, ピアノ線の引抜き時間は約 $20 \mathrm{~ms}$ であ った。チューブ内にアークを点弧すると, 溶発がスがチュ ープ両端から激しく放出した。

〈2・2〉 電界の強さ-電流特性 低電流領域の電界の強 さ一電流特性は, 以下のようにして求めた(10)。チューブ長 を $10,20,30 \mathrm{~mm}$ と変えてアーク電圧-電流特性を計測 する。この結果から, 電流をパラメータとしたアーク電圧一 アーク長特性を求め, その特性の傾きから電界の強さを求 める。こうすることにより, チューブ内陽光柱の電界の強 さが得られる。なお，アークの点弧期間は $0.35 \mathrm{~s} と し, ~$ その間, 電極間電圧を連続的に計測し, その平均值をア一 ク電圧とした。

PE, PVC, PTFE, PP, PMMA, POM, PA, 扔 $ょ$ びABSアークに対し，チューブ孔径を2，4，6 $\mathrm{mm} \phi$ と 変え, 電界の強さ一電流特性を求めた。それらのうち, 千
ューブ孔径 $4 \mathrm{~mm} \phi$ の場合のものを図 2 に示す。同図から 次のことがわかる。どのプラスチックアークの場合も, 電 界の強さは電流が増加するに従って減少する。電界の強さ は, PE, PP, PA, ABS, POM, PMMAアークが高 く, PVCアークが中程度で PTFEアークがかけはなれて 低い。また, 参考のため, 溶発のない器壁安定化空気アー クの電界の強さ ${ }^{(10)(13)}$ も図 2 亿示した。PTFEアーク以外 のプラスチック溶発アークの電界の強さ一電流特性は, 空 気アークのそれを上回わっていることがわかる。チューブ 孔径 2 および $6 \mathrm{~mm} \phi$ の場合も同様の傾向であった。

\section{3. 大電流領域（20５00 A）における電界の強さ}

〈3・1〉実験方法図1に扔いて,いったん10 Aの 低電流アークをプラスチックチューブ内に点弧し，0.2 $\mathrm{s}$ 後, 気中投入器を投入することによって, あらかじめ充電 して扔いたコンデンサ電源 $(800 \mu \mathrm{F}$, 充電電圧： $1.5 \sim 5$ $\mathrm{kV})$ から，インダクタンス $(66 \mathrm{mH}, 1.5 \Omega)$ を介して大 電流を注入した (14)。

アーク電圧および電流はディジタルストレージオシロス コープを用いて同時に記録した。チューブ材料は，低電流 領域において電界の強さに顕著な差が見られた $\mathrm{PE}$, PVC，およびPTFEとした。

〈3・2〉 アーク電圧・電流波形 チューブ長 $20 \mathrm{~mm}$, 充電電圧 $5 \mathrm{kV}$ の場合のPE アークの電圧・電流波形を図 3 に示す。アーク電流の波形は, 半周期 $25 \mathrm{~ms}$ の正弦波状 である。チューブ孔径を細くすると，電流のピーク值はや や低くなり，チューブ孔径 $2 \mathrm{~mm} \phi$ の場合，約 $430 \mathrm{~A} ， 6$ $\mathrm{mm} \phi$ の場合, 約 $460 \mathrm{~A}$ である。一方,アーク電圧は, 千 ューブ孔径が細いほうが高い。

〈3.3〉電圧-電流特性 図 3 に示したアーク電圧抢よ び電流波形から，アーク電圧一電流特性が得られる。アー ク電圧は, Ibrahim ${ }^{(3)}$ が PMMAアークの場合について示 しているように，電流上昇期間と電流下降期間とでは，上 昇期間のほうが高く，上ステリシスがある。チューブ孔径 が細いほどヒステリシスが大きい。今回の計測範囲では, チューブ孔径 $2 \mathrm{~mm} \phi$ の場合, 電流上昇期間のアーク電圧 は，電流下降期間のそれより最大で $10 \%$ 高かった。

図 4 にチューブ孔径が $4 \mathrm{~mm} \phi$ の場合で, 電流上昇期間 に扔けるアーク電圧一電流特性を示す。コンデンサ充電電 压が $1.5 \mathrm{kV}$ と $5 \mathrm{kV}$ の場合の結果を示している。20〜150 Aの電流領域で，両方の結果はほ浔同じである。また， アーク電流を一定とすると,アーク電圧は, チューブ長が 長くなるに従って比例的に増加していることがわかる。

以上のような傾向は，PVC および PTFEアークの場合 に関しても同様であった。

〈3・4〉 電界の強さ-電流特性図4 の計測結果を近似 曲線（実線）で表し，〈2・2〉節と同様にして電界の強さ一電 流特性を求めた。他のチューブ孔径およびチューブ材料に 関しても同様にして求めた。その結果を図 5 に示す。直流 電源を用いて求めた 2 30 A の低電流領域の結果も併記 


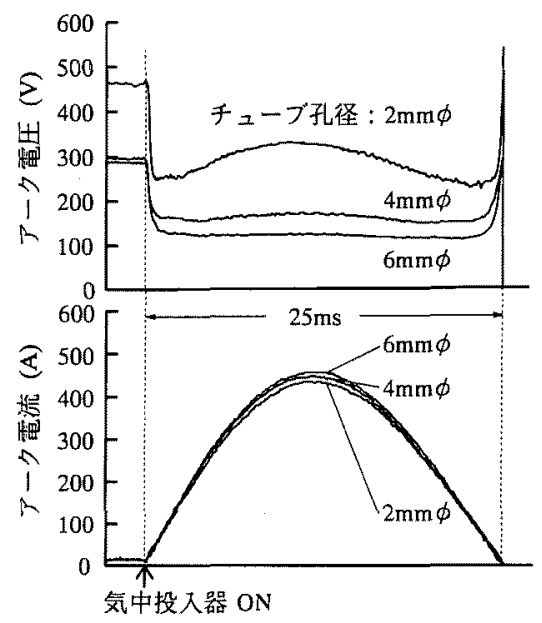

図 3 コンデンサ電源を用いた場合の PE アークの 電压・電流波形

Fig. 3. Voltage and current waveforms of PE arc using capacitor bank power supply.

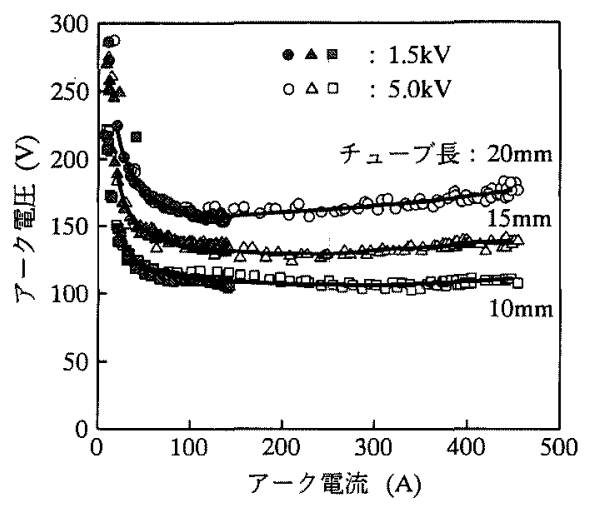

図 4 チューブ長をパラメータとした PEアークの 電圧一電流特性

Fig. 4. Voltage-current characteristics of PE arc for various tube lengths.

した。直流電源を用いて計測した結果とコンデンサ電源を 用いて計測した結果とはほほ連続している。

同図から次のことがわかる。電界の強さは，どのチュー ブ孔径抢よび材料の場合でも，電流の増加とともにいった ん隇少し，その後は増加に転じる。電界の強さが上昇し始 めると, チューブ材料による電界の強さの差が縮まる。チ ューブ孔径 $2 \mathrm{~mm} \phi$ の場合, 電流が $100 \mathrm{~A}$ 以上になると, 3 種類のアークの電界の強さは接近している。 $4 \mathrm{~mm} \phi$ の 場合, 電流 $30 \mathrm{~A}$ 以上で, PEアークの電界の強さと PVC アークのそれとの間には明らかな差異は見られず， $300 \mathrm{~A}$ 以上になると, PTFEアークの電界の強さがそれらへ近 づいている。 $6 \mathrm{~mm} \phi$ の場合も同様な傾向がうかがえる。 このように, プラスチック溶発アークの電界の強さは, 低 電流においてはチューブ材料依存性が顕著であるが, 大電 流になるほどチューブ材料依存性がなくなるといえる。な

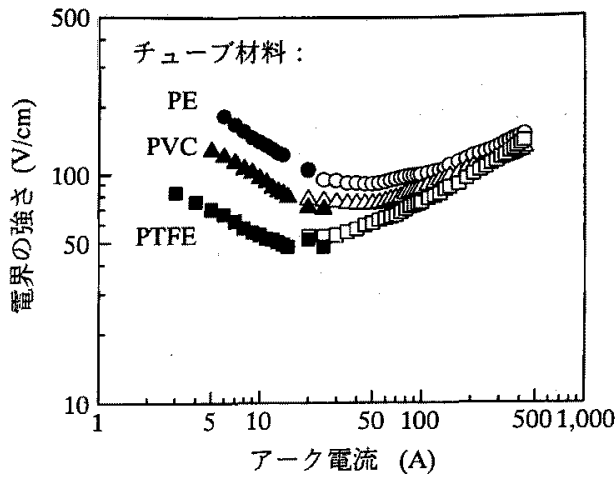

(a) $チ$

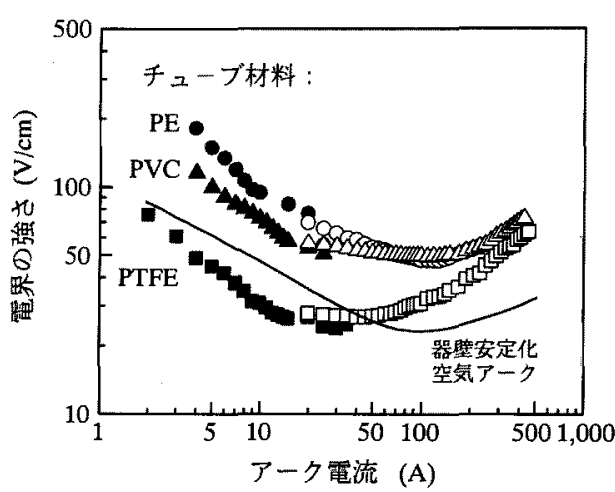

(b) チューブ孔彺: $4 \mathrm{~mm} \phi$

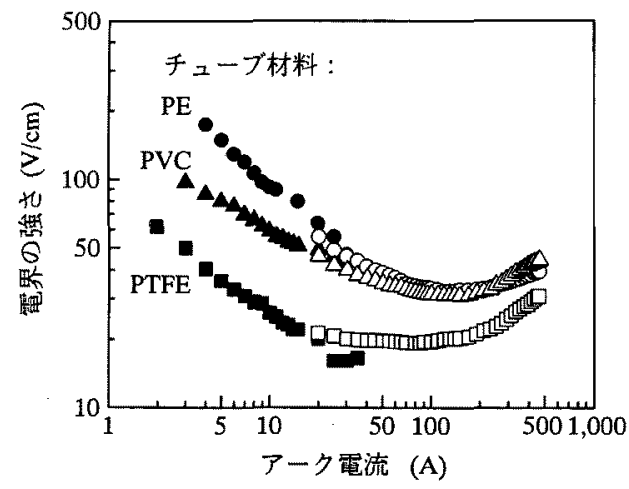

(c) チュープ孔径 : $6 \mathrm{~mm} \phi$

○、・, 回: 直流電源を用いた夷測值,

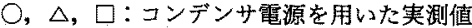

図 $5 \mathrm{PE}, \mathrm{PVC}$ ，およびPTFEアークの 電界の強さ一電流特性

Fig. 5. Electric field strength-current characteristics of PE, PVC, and PTFE arcs.

お, 図4(b)には, 器壁安定化空気アークの電界の強 さ(10)(13)も示した。PE抢よびPVCアークの電界の強さ は, 大電流領域でも空気アークのそれより高いことがわか る。一方, PTFEアークの電界の強さは, 大電流領域に なると空気アークのそれより高くなることがわかる。

また, チューブ孔径が細いほど, 電界の強さが最小とな 
る電流值が低くなる傾向にあることがわかる（付図 1 参 照)。例えば, PEアークの場合, その電流值は, チュー

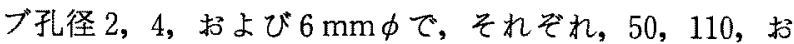
よび140Aである。PVCアークの電界の強さも，PEア 一クの場合と同様な電流值で最小となるが, PTFE アー クの場合は，より低い電流值で最小となる。

な枋, 大野らは，チューブ孔径 $5 \mathrm{~mm} \phi$ PTFEアー クに関し，200 A 以下の電流領域における電界の強さ-電 流特性を計測している(15)。その特性は，今回の訐測結果 であるチューブ孔径 $4 \mathrm{~mm} \phi と 6 \mathrm{~mm} \phi$ の曲線の間に位置 する。

\section{4. チューブ損耗量および溶発ガス量}

溶発アークにおいては, チューブの内壁からプラスチッ ク材料が溶発し，そのガスがチューブの両端から噴き出 す。そこで, チューブ損耗量および溶発ガス量と電界の強 さとの関係を計測した。

〈4・1〉低電流領域長さ $20 \mathrm{~mm}$ の各種プラスチッ クチューブ内に 10 および $20 \mathrm{~A}$ のアークを $0.35 \mathrm{~s}$ 間点弧 しアアーク点弧前のチューブの質量と消弧後の質量とを電 子天科で測定し，その差をチューブ損耗量とした。

チューブ孔径 $4 \mathrm{~mm} \phi$ の場合のチューブ損耗量と電界の 強さとの関係を図6(a)に示す。当初，チューブ損耗量が 多いほど，電界の強さが高くなると考えた。しかしなが ら，図6(a)において，そのような傾向は見られない。例 として, 電界の強さが最も低いPTFEアークと次に電界 の強さの低いPVCアークとを比較してみる。電流 $10 \mathrm{~A}$ の場合, PTFEアークのチューブ損耗量は, 8 種類のアー クのうち約 $15 \mathrm{mg}$ と最も少ないものの, PVCアークのそ れは, 約 $55 \mathrm{mg}$ と最も多い。電流 $20 \mathrm{~A}$ の場合も同様な傾 向を示している。チューブ孔径 $2 \mathrm{~mm} \phi$ の場合も同様な傾 向であった。なお，図6(a)の損耗量から，チューブの損 耗厚さを計算したところ，本実験条件下では $0.2 \mathrm{~mm}$ 以 下であった。

チューブ損耗量と電界の強さとの相関が図 6(a)のよう に明白でない原因は，チューブ損耗量のすべてがガス化す るとはかぎらないからである。実際，PVCアークゃ ABS アークなどでは，他のアークに比心゙てかなり多くのカーボ ン微粒子（すす）が発生した。そこで，純粋にガス化した 量，すなわち溶発がス量を計測した。その方法を図 1 に示 す。アクリル製（板厚： $5 \mathrm{~mm})$ の密閉容器 $(900 \times 900 \times$ $700 \mathrm{~mm}$, 軽量アルミはり付き) 内にアーク装置を閉じ込 め, 排気ロにポリエチレン袋 $\left(2,000 \mathrm{~mm}^{2} \times 150 \mathrm{~mm} \sim 3\right.$, $200 \mathrm{~mm}^{2} \times 400 \mathrm{~mm}$ ) を取り付けた。アークを $0.35 \mathrm{~s}$ 間点 弧したところ，ポリエチレン袋が膨らんだ。十分に時間を 経た後，ポリエチレン袋に捕集されたガスを水中でメスシ リンダに移し，体積を測定した。ポリエチレン袋に補集さ れた気体のほとんどは，チュープ材料からの溶発ガスでは なく，発生した溶発ガス量に押し出された空気である。そ れゆえ，溶発ガスに水溶性成分があったとしても，補集気

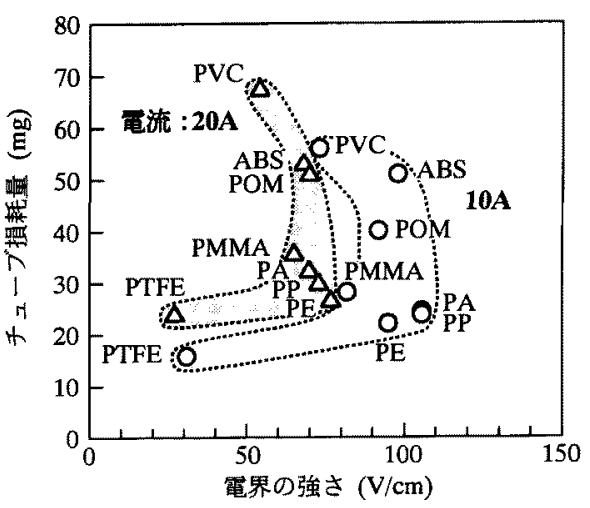

(a) チュープ損耗量

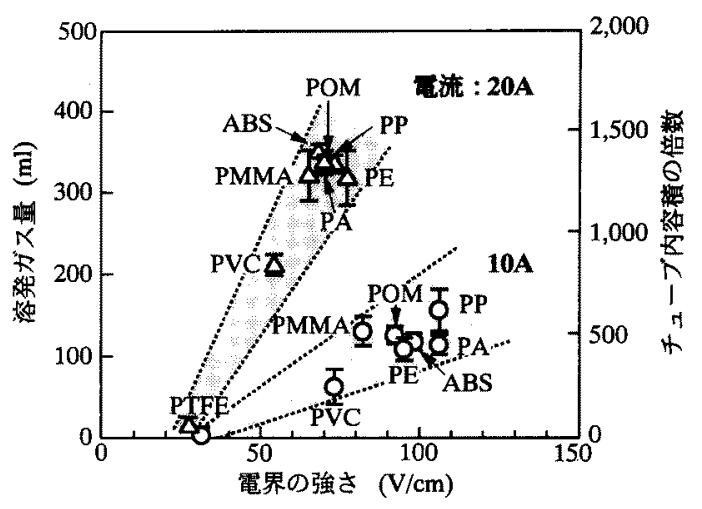

（b）溶発ガス量

図 6 低電流領域におりるチューブ損耗量および 溶発ガス量の電界の強さ依存性

Fig. 6. Ablated mass and gas volume as a function of electric field strength in lower current range.

体のうち水に吸収される量は無視できる。

チューブ長 $20 \mathrm{~mm}$, 孔径 $4 \mathrm{~mm} \phi$ の場合の溶発ガス量と 電界の強さとの関係を図 6(b) に示す。同図から，電流を 一定とすると，溶発ガス量はPTFEアークの場合が最も 少なく，続いて PVCアーク，その他のアークの順に多く なっており，電界の強さが大きいほど，溶発がス量が多く なる傾向にあることがわかる。また，電流が大きいほう が，溶発ガス量が多いこともわかる。横軸の電界の強さを エネルギーに変えると，溶発ガス量とエネルギーとの関係 は，ほほ直線となる傾向にある。同様な傾向がチューブ孔 径 $2 \mathrm{~mm} \phi$ の場合にも見られた。

〈4・2〉大電流領域 PE，PVC，扔よび PTFEアー クに関し，コンデンサ電源を用いて大電流を流した場合の チューブ損耗量および溶発ガス量を，前節同様にして計測 した。コンデンサ電源から大電流を注入する前に, 直流 $10 \mathrm{~A}$ のアークを $0.2 \mathrm{~s}$ 間点弧させたため，その分の損耗量 および溶発がス量を全体の計測量から差し引いた。

チューブ孔径 $4 \mathrm{~mm} \phi$, チューブ長 $20 \mathrm{~mm}$ の場合のチュ ーブ損耗量枋よび溶発ガス量とピーク電流との関係を図 7 に示す。(a)図から,チューブ損耗量は, PEアークの場 


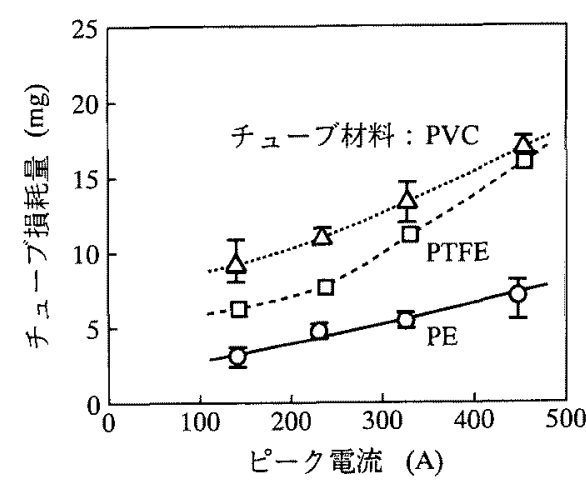

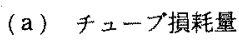

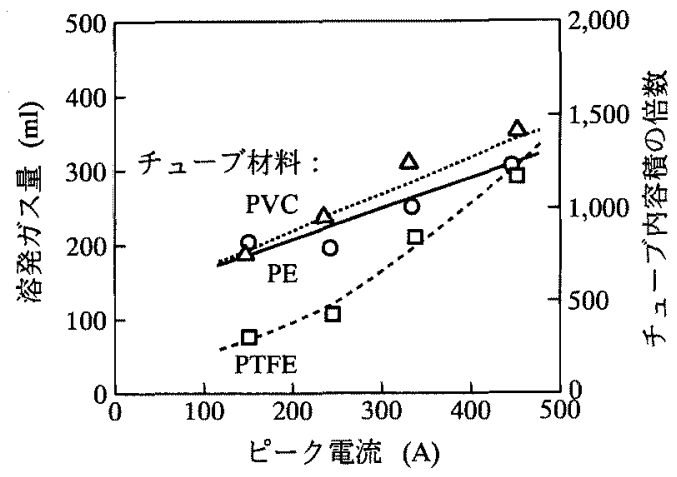

(b) 溶発ガス量

キューブ孔径： $4 \mathrm{~mm} \phi$ チューブ唇: $20 \mathrm{~mm}$

図 7 大電流領域におけるチューブ損耗量および 溶発ガス量のピーク電流依存性

Fig. 7. Ablated mass and gas volume as a function of peak current in higher current range.

合が最も少なく, PTFEアーク, PVCアークの順に多く なっていることがわかる。

Müller ${ }^{(8)}$ は, PEお および PTFEアークに関し, 700〜 3,600 A の電流領域でチューブの損耗体積を計測してい る。その結果，PTFEのほうが PEの損耗体積よりも大き いことを示している。これは，図7(a)の結果と一致する。

図 7(b)加ら, 溶発がス量もピーク電流の增加とともに 増加していることがわかる。PEアークと PVCアークと の間には顕著な違いはなく，ピーク電流の増加とともに緩 やかに増加している。これらと比較すると，PTFEアー クの場合, 溶発ガス量はピーク電流の増加に伴い急激に増 加している。すなわち，PTFEアークの溶発ガス量は， ピーク電流が小さい場合, PEやPVCアークのそれの1/ 3 程度であるが, ピーク電流が $330 \mathrm{~A}$ 以上になると, $\mathrm{PE}$ やPVCアークのそれとほ四等しくなる。

図 7(b)の溶発ガス量とピーク電流との関係と, 図 5 (b)の $50 \mathrm{~A}$ 以上の電界の強さと電流との関係とはよく似 た傾向にある。そこで, 両図から電流の実効值をパラメー 夕にとって, 溶発ガス量と電界の強さとの関係を求めてみ た。その結果を図 8 に示す。同図から，溶発ガス量は，チ

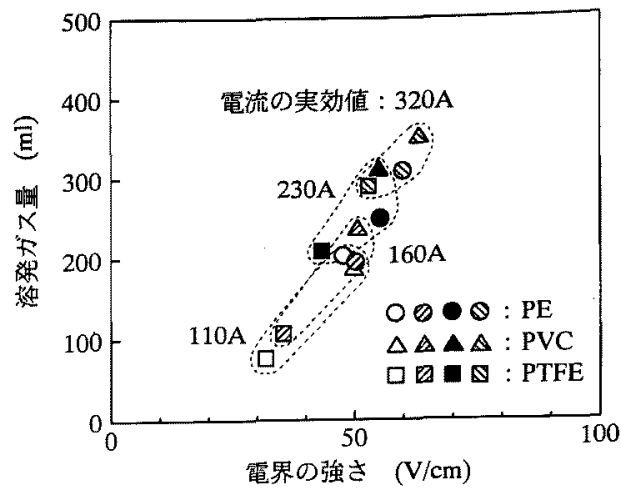

チューブ孔径：4 mm $\phi$, チューブ長：20 mm

図 8 大電流領域における溶発ガス量と電界の強さ との関係 (パラメータ：電流の実効值,

$$
\text { チェーブ材料) }
$$

Fig. 8. Relation between ablation gas volume and electric field strength in higher current range (parameter : current rms, tube material).

ューブ材料抢よび電流によらず，電界の強さに対し直線的 に増加していることがわかる。

\section{5. 考察}

プラスチック溶発アークの電界の強さは, 低電流ではチ ューブ材料依存性があるが，大電流になるとその依存性が 小さくなることがわかった。この原因について考察してお $<0$

一般に,アーク放電に扎いて, 電界の強さ $E$, アーク 電流 $I$, 導電半径 $R_{c}$, 導電率 $\sigma, ア ー ク 中 心 か ら の$ 距離 $r$ との間には，次式が成立する。

$$
E=I / \int_{0}^{R_{c}} \sigma(r) \cdot 2 \pi r d r
$$

上式は，のが高いほど，また $R_{\mathrm{c}}$ が大きい添ど $E$ が低くな ることを意味している。

図 9 に, PE 蒸気(11), PVC 蒸気(16), PTFE 蒸気(16)，お よび純粋空気 ${ }^{(17)}$ の導電率-温度特性を示す。低電流溶発ア ークでは, アーク柱への注入エネルギー（電界の強さ $\times$ 電 流）が小さく，中心温度がたかたが $10,000 \mathrm{~K}$ 程度(11)であ るので, 導電領域の平均的な温度はそれよりかなり低い。 導電領域の平均温度が 6,000 ～ $8,000 \mathrm{~K}$ であるとすると, その温度範囲の $\sigma$ を高い順に並べると, (1) PTFE 蒸気, (2) PVC 蒸気，(3) PE 蒸気となる。從って，R $R_{c}$ が一定 であるとすると，(1)式からEの高い順に並べると， (1) PEアーク, (2) PVCアーク, (3)PTFEアークと なる。

また, プラスチック溶発アークでは，チュープ内壁から 発生する溶発ガスがアーク中央に向かって流れる。そのた め, 導電領域が狭められ， $R_{c}$ が小さくなり，（1)式に従 って $E$ が高くなる。この溶発ガス量が材料によって異な るために，材料依存性が明確となる。図 6(b) の結果はこ のことを示している。 


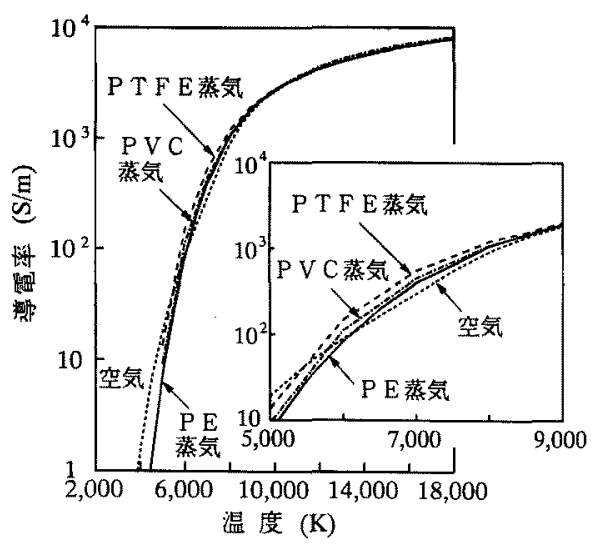

図 $9 \mathrm{PE}, \mathrm{PVC}$, および PTFE 蒸気の 導電率-温度特性（1 atm）

Fig. 9. Electrical conductivity of PE, PVC, and PTFE vapors as a function of temperature ( $1 \mathrm{~atm}$ ).

空気の $\sigma$ は，6,000〜8,000 の温度範囲ではプラスチック 蒸気のそれに比べて低く，そのため導電率のみからみれ ば,（1）式に従って空気アークのEは最も高くなるはず である。そうならない原因は, 空気アークでは, 溶発ガス がないために，R からである。例外的に, PTFEアークのEは空気アーク の $E$ より低い。これは, PTFEアークの溶発ガス量が極

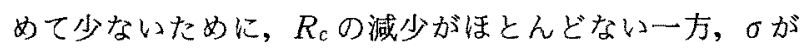
空気より高いからである。

大電流になると, アーク柱への注入エネルギーが増加 し, 導電領域の平均温度が $10,000 \mathrm{~K}$ 以上になる。そうす ると, 図 9 からわかるように, 材料による導電率の違いが なくなる。一方, 図 7(b) は電流の増大に伴って溶発ガス 量の材料による違いが小さくなることを示している。従っ て，(1)式の $\sigma$ と $R_{c}$ が材料によって違わなくなるため, $E$ の材料依存性が小さくなる。

\section{6. まと め}

種々のプラスチック材料 (PE, PVC, PTFE, PP, PMMA, POM, PA, ABS) のチューブ内に点弧させた 大気圧アーク陽光柱の電界の強さを, 2〜500 A の電流領 域において計測した。一方，その結果を検討するために， チューブ損耗量㧍よび溶発ガス量を計測した。本論文で得 られた主な結果を以下に要約する。

（1）低電流領域（2３0 A) に扔ける電界の強さは, チューブ材料によって異なる。大別すると，PE，PP， PA, ABS, POM, PMMA ークの電界の強さが高く, PTFE が最も低く，PVCがそれらの中間に位置する。

（2）低電流領域において，電流を一定とするとチュー ブ損耗量と電界の強さとの相関は明らかでないが, 溶発が ス量と電界の強さとの間には正の相関がある。

(3) $\mathrm{PE}, \mathrm{PVC}$ およびPTFEアークの電界の強さ
は, 2〜500 A の電流領域に扔いて，電流の増大とともに いったん低下するが，その後上昇する。大電流になるほど チューブ材料依存性がなくなる。

（4）大電流領域 $(100 \sim 500 \mathrm{~A})$ における PE, PVC, および PTFEアークの溶発ガス量は，ピーク電流の增大 とともに增加する。その増加割合は，PEやPVCと比心゙ PTFEアークのほうが高い。

（5）大電流領域に拈けるプラスチックアークの電界の 強さと溶発ガス量との関係は，プラスチック材料や電流值 が変わっても，ほ果一つの直線に乗る。

以上のような特性を呈するプラスチック溶発アークの電 界の強さを決める要因は, 低電流領域においては，プラス チック蒸気の導電率一温度特性扔よび溶発ガスのアーク導 電断面積を狭める効果が，大電流領域においては主として 後者が支配的であることを明らかにした。

終わりにあたり，卒業研究として本研究の一部に従事さ れた山根義昭君，岡 章治君に謝意を表す。また，本研 究の一部は, 文部省科学研究費補助金の援助を受けて行わ れた。

(平成 6 年 1 月 27 日受付)

\section{文献}

(1) N. N. Ogurtsova, I. V. Podmoshenskii \& V. L. Smirnov "Ohmic Superheating in the Dense Plasma of a Capillary Discharge", High Temp., 14, 1 (1976)

(2) L. Niemeyer: "Evaporatoin Dominated High Current Arcs in Narrow Channels", IEEE Trans. Power Apparatus. Syst, PAS97, 950 (1978)

(3) E. Z. Ibrahim: "The Ablation Dominated Polymethylmetha crylate Arc", J. Phys. D : Appl. Phys., 13, 2045 (1980)

(4) P. Kovitya \& J. J. Lowke: "Theoretical Predictions of Abla. tion-Stabilised Arcs Confined in Cylindrical Tubes", ibid., 17, 1197 (1984)

(5) A.D.Stokes, H. Sibilski \& P. Kovitya: "Ablation Arcs II: Arcs in Plastic Materials and in Boric Acid", ibid., 22, 1702 (1989)

(6) G. R. Jones, N. Y. Shammas \& A. N. Prasad: "Radiatively Induced Nozzle Ablation in High-Power Circuit Interrupters", IEEE Trans. Plasma Sci., PS-14, 413 (1986)

(7) C. B. Ruchti \& L. Niemeyer: "Ablation Controlled Ares", ibid., PS-14, 423 (1986)

(8) L. Müller: "Modelling of an Ablation Controlled Arc", $J$. Phys. D: Appl. Phys., 26, 1253 (1993)

(9) P. Kovitya: "Ablation-Stabilized Arcs in Nylon and Boric Acid Tubes", IEEE Trans. Plasma Sci., PS-15, 294 (1987)

（10）澺川・䛈原・鬼頭：「ポリエチレンチューブ内のアーク陽光柱の電 界の強さと放射パワー」, 電学諭 A, 106, 588 (昭 61-12)

（11）滝川・概原・宮下・作田・鬼頍：「ポリエチレンチューブを貫通す るアーク陽光柱の中心付近温度分布の計瞧), 同上 A, 112, 47 (平 4-1)

(12）滝川・大西・榊原：「ポリエチレンアークシース領域の流速計測」, 同上 A, 112,849 (平 4-10)

（13）鬼頭・宮地・足立：「器壁安定化空気アーク陽光柱の電界の強さ」, 同上 A, 96, $280($ 昭 51-6)

（14）榊原・鬼頭・宮地・池田：「放射のある安定化空気アーク踼光柱の 電界の強さ」, 同上A, 99, 592 (昭 54-12)

(15) 大野・長綶・鬼頭：「PTFE 分解ガス混入空気アークの䉓界の強さ 一電流特性」, 平 5 電気関係学会東海支部連大, No. 159, p. 80

(16) P. Kovitya: "Thermodynamic and Transport Properties of Ablated Vapors of PTFE, Alumina, Perspex, and PVC in the Temperature Range 5000-30000K", IEEE Trans. Plasma Sci., PS-12, 38 (1984)

（17）作田・鬼頭・宮地：「銅蒸気が混入した高温架気の導電率，熱伝導 率およびエンタルピー」, 電学論 $\mathrm{A}, 101,241$ (昭 56-4) 


\section{付 録}

図 5 の電界の強さ-電流特性を, チューブ孔径をパラメ ータとして書き変えたものを付図 1 に示す。また，付図 2

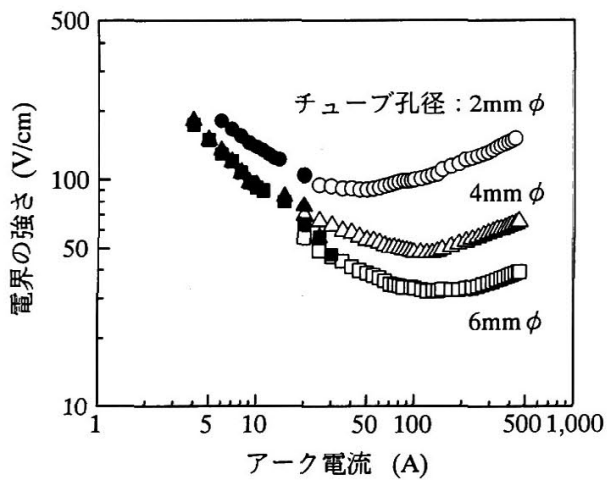

(a) PEアーク

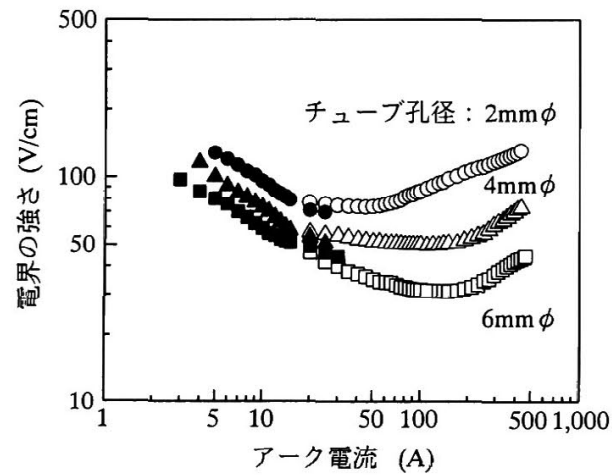

(b) PVCアーク

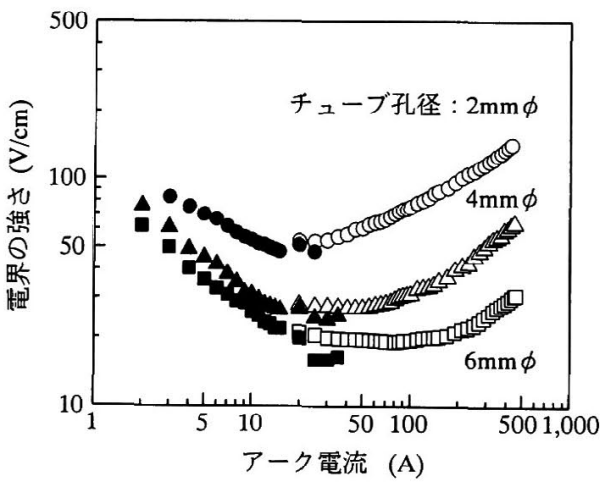

(c) PTFE ーク

付図 1 チューブ孔径をパラメータとした 電界の強さ-電流特性

app. Fig. 1. Electric field strength-current characteristics of PE, PVC, and PTFE arcs with tube inner diameter as a parameter.
に，チューブ孔半径 $R$ で規格化した $R E-I / R$ 特性を示 す。電界の強さ一電流特性は,チュープ孔半径でほぼ規格 化できることがわかる。

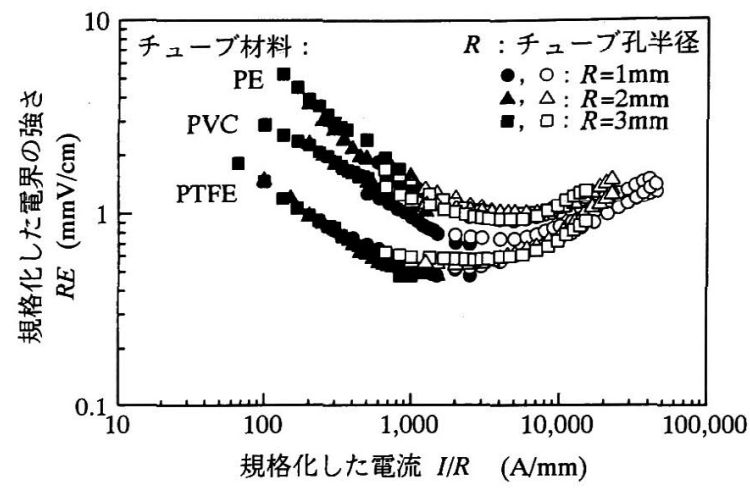

付図 2 チューブ孔半径で規格化した電界の強さ app. Fig. 2. Electric field strength of PE, PVC, and PTFE arcs normalized by tube inner radius.

滝川浩史（正員） 1962 年 2 月 15 日生。1984 年 3 月豊橋

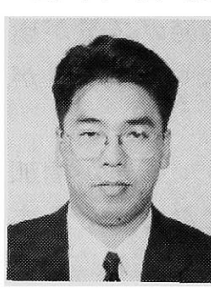
技術科学大学電気・電子工学課程卒業。1986 年 3 月同大学大学院工学研究科電気・電子工学専攻修 士課程修了。1987 年 1 月〜 1989 年 12 月カナ ダ・シャーブルック大学プラズマ技術リサーチセ ンター研究員。以後, 豊橋技術科学大学電気・電 子工学系助手を経 $\tau$, 現在, 釧路工業高等専門 学校電気工学科助教授。工学博士。1992 年電気 関係学会東海支部連合大会奨励賞受賞。応用物理学会会員。

大 西 隆二(学生員) 1969 年 7 月 27 日生。1992 年 3 月豊 橋技術科学大学電気・電子工学課程卒業。1994 年 3 月同大学大学院工学研究科電気・電子工学専 攻修士課程修了。同年 4 月三浦工業(株) 入社, 現在に至る。

榊 原 建 樹 （正員） 1967 年 3 月名古屋大学工学部電気学科

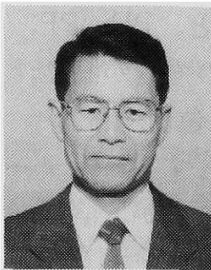
卒業。1 972 年 3 月同大学大学院工学研究科博士 課程修了。以後, 名古屋大学工学部助手などを 経て, 現在, 豊橋技術科学大学電気・電子工学系 教授。工学博士。応用物理学会, 日本太陽エネ ルギー学会, IEEE 会員。 